\title{
Suicide in Prisoners: An Italian Contribution
}

\author{
E. Cinosi ${ }^{*}$,a, G. Martinotti $^{\mathrm{a}}$, L. De Risio ${ }^{\mathrm{b}}$ and M. Di Giannantonio ${ }^{\mathrm{a}}$ \\ ${ }^{a}$ Neuroscience and Imaging Department, Chair of Psychiatry, “G. d' Annunzio” Univesity, Chieti, Italy \\ ${ }^{b}$ Institute of Psychiatry and Psychology, Catholic University Medical School, Rome, Italy
}

\begin{abstract}
It is well-known that suicidal behavior is very common among criminal justice clients, both among those serving community sentences and among prison inmates. Suicide rates among prisoners are considerably higher than in the general population. There is great concern over high rates of suicide and suicidal behavior in prisons, with suicide prevention becoming a major challenge for penal institutions in many countries. In particular, Italian prisons are facing an important crisis. The aim of the present descriptive review is to investigate suicide in prisons, with particular attention to the Italian situation. To date, there are no comprehensive data on this phenomenon for reasons that are critically discussed in this paper. First, we focus on epidemiology, and try to summarize existing heterogeneous data. Demographic, criminologi$\mathrm{cal}$ and clinical risk factors associated with suicide in prisoners are then examined. Understanding the process by which certain prisoners, under specific circumstances, contemplate, plan and decide to end their lives is critical to suicidal prevention, as discussed in the third part of the review. Finally, we suggest possible future investigations to improve detection of specific risk factors and we discuss the challenges to be faced in order to decrease suicide rate among prisoners.
\end{abstract}

Keywords: Suicide, prison, jail, remand, penal.

\section{INTRODUCTION}

Death by suicide and suicidal behavior is a crucial concern worldwide (Hakansson, 2010; Diekstra, 1993). Globally, suicide accounts for 16 deaths per 100.000 citizens each year (WHO, 2005). Suicidal behavior is more common among criminal justice clients, both among those serving community sentences and among prison inmates (Sattar, 2003; Borrill, 2003; Kokkevi, 1995). Nowadays, there is great concern over the high rates of suicide and suicidal behavior in prisons, with suicide prevention becoming a major challenge for penal institutions in many countries (Ronald, 2006).

More than 10 million people are imprisoned worldwide (Fig. 1). The number of people in prisons has been increasing in more than two-thirds of countries worldwide in the past decade and rose by more than 1 million from the late 1990s to 2006-08 (Walmsley, 2009). Rates of imprisonment have especially risen in North and Central America, Asia and Oceania (Fazel, 2011). Italian prisons are facing an important crisis. In Italy, according to recent estimates, there are 66.897 prisoners, of which 2.808 women and 24.197 foreigners (Ministero della Giustizia, 2011). The 206 institutions constituting the Italian prison system are designed to hold 45.700 convicts; prison population therefore exceeds this number by 21.197 people, with only one out of the twenty Italian

\footnotetext{
*Address correspondence to this author at the Neuroscience and Imaging Department, Chair of Psychiatry, “G. d' Annunzio” Univesity, Chieti, Via dei Vestini 131, 66100 Chieti, Italy; Tel: +39 0871 358931;

Fax +39 0871 358916; Cell: 0039 3497366158;

E-mail: educuoreviola@hotmail.it
}

regions having prisons that are not overcrowded (Fig. 2). According to the Council of Europe, Italian jails are the third most overcrowded in Europe, after Serbia and Greece (ANSA, a2013). The 47-nation human rights organization stated that, in Italy, there are 147 inmates for every 100 beds, compared with a European average of 105. Italy is also third with respect to number of inmates awaiting trial, after Ukraine and Turkey. Italian prisons are currently filled to $142.5 \%$ of their capacity, compared to a European average of 99.6\%. In January 2013, the European Court of Human Rights in Strasbourg fined Italy $€ 100,000$ for the inhumane living conditions in its prisons, ordering the government to implement changes within a year. In May 2013, in final ruling, Italy was forced to resolve prison overcrowding (European Court of Human Rights finds jails 'inhumane, degrading') (ANSA, b2013). This definitive ruling means Italy now has one year to solve prison overcrowding and to pay damages to victims. Conditions in Italian prisons have long been criticized by human rights groups. Italy picked up a record haul of fines in 2012 at the European Court of Human Rights, which ordered it to pay a total of 120 million Euros to citizens whose rights had not been respected. This is the highest annual fine ever collected from any of the 47 states members of the Council of Europe. Italy is regularly fined by the court for the slowness of its legal system, which means Italians' right to have justice in a reasonable time frame is frequently violated. Meanwhile, Article 27 of the Constitution of the Italian Republic - which states that detention should have educational purposes - seems to be a dead letter inside what some have described as "hell" (ANSA, 2012). 


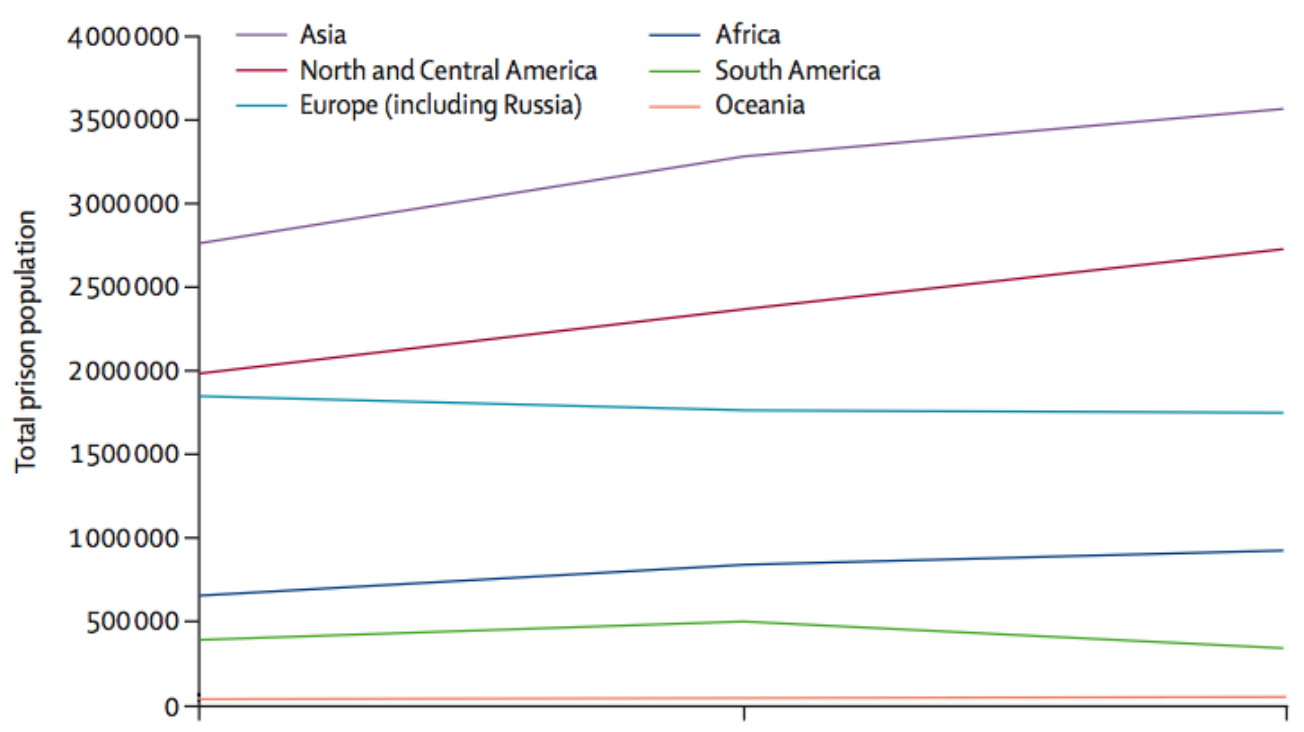

Fig. (1). Prison population by continent. More than 10 million people are imprisoned worldwide. The number of people in prisons has been increasing in more than two-thirds of countries worldwide in the past decade and rose by more than 1 million from the late 1990s to 2006-08 Modified from: Fazel S, Baillargeon J, The health of prisoners. Lancet 2011; 377: 956-65.

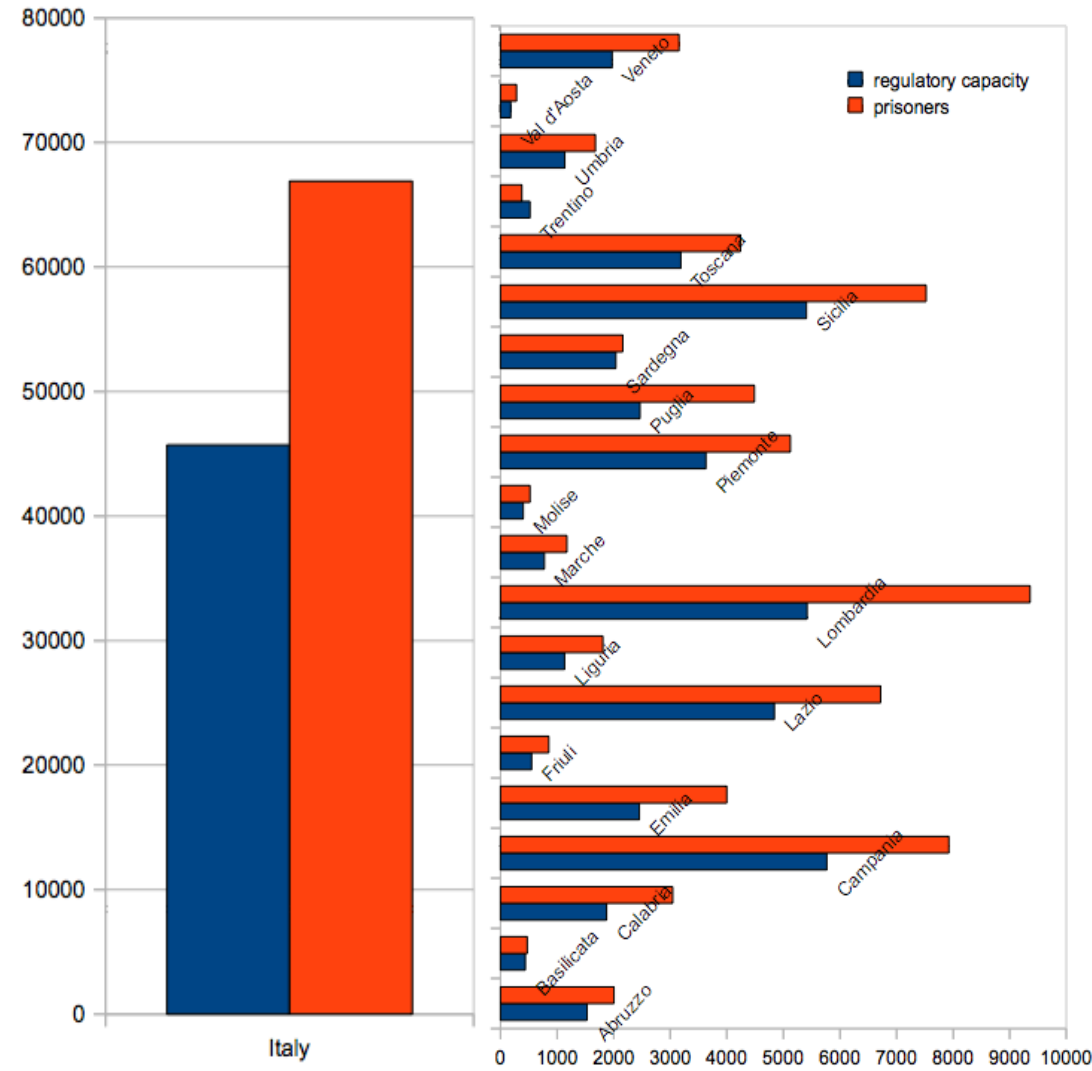

Fig. (2). Overcrowding in italian prisons. The 206 institutions constituting the Italian prison system are designed to hold 45.700 convicts; prison population (66.897 prisoners, of which 2.808 women and 24.197 foreigners) therefore exceeds this number by 21.197 people (on the left), with only one out of the twenty Italian regions having prisons that are not overcrowded (on the right). Italy's jails are the third most overcrowded in Europe.

Edited from: Ministero della Giustizia. Detenuti presenti-Aggiornamento al 31 Dicembre 2011. Available online: http://www.giustizia.it/giustizia/it/mg_ 1_14_1.wp?previsiousPage=mg_1_14\&contentId=SST720006

The aim of the present descriptive review is to investigate suicide in prisons, with particular attention to the Italian situation. To date, there are no comprehensive data on this phe- nomenon for reasons that are critically discussed in this paper. 


\section{METHODS}

PubMed, Embase and Cochrane electronic databases were searched for any literature article on suicide and suicidal behavior in prisons published in the last forty years (until May 2013). We primarily focused on the most recent, significant and comprehensive contributions. Search terms included: "suicide”, "prison”, “jail”, "remand”, "penal”. The terms were combined to elicit the relevant articles. In our critical, descriptive review of literature we chose to include articles and expert opinions that summarize, analyze and integrate the complex findings in this field. The aim of our paper was to give an Italian contribution to the understanding of suicide in prisons and to provide a valuable document for anyone wishing to conduct further research in this area.

\section{EPIDEMIOLOGY}

Prison inmates are recognized as a population with a high burden of disease due to a wide range of physical and mental health problems (Table 1). Several studies have reported risky sexual behaviors and substance misuse among people who have served time in prison, revealing their extreme vulnerability to sexually transmitted diseases (David, 2003), viral hepatitis (Butler, 2004), drug dependence (Kouri, 1997) and mental health problems (Fazel, 2002). A number of studies view death as the ultimate consequence of these health problems. Most mortality studies have focused on deaths occurring while in custody and showed that prisoners are more likely to die prematurely compared to people who have never been in prison (Salive 1990; Dalton 1999; Wobeser 2002), and that suicide is one of the leading causes of in-prison death (Beckett, 1987; Joukamaa, 1997).

Suicide rates among prisoners are considerably higher than in the general population (Fazel, 2008; Durand 1995; Karminia, 2007) and are increasing significantly worldwide (Hayes, 1989; Laishes, 1997; Fruehwald, 2003; Preti, 2006; Dooley, 1990). In England and Wales, the age-standardized rate of suicide among male prisoners is 5 times higher than in the general population- a proportionate excess that has been increasing since 1978 (Fazel, 2005). In a study con- ducted in 12 western countries between 2003 and 2007, suicide rates were estimated to be, on average, between 50 and 150 suicides per 100000 male prisoners per year, with higher rates in northern European countries and lower rates in Canada, Australia and New Zealand (Fazel, 2010; Green 1993). In particular, Italian prisons are facing a deep crisis; from 2002 to 2012, almost one thousand deaths have been registered (Ministero di Giustizia, Ristretti Orizzonti, 2013). Fig. (3) shows the burden of unnatural deaths un Italian prisons: self-inflicted death is the leading cause (518 out of 915 prisoners committed suicide, $56 \%$ ), the second cause is sickness $(183,20 \%)$, followed by death under unclear circumstances (177, 19\%). Finally, 26 prisoners died of drug overdose and 11 were victims of homicide. Hence, in Italy, roughly 60 prisoners commit suicide each year; prisoners are nine times more likely to attempt suicide than ordinary citizens, and the rate is quickly increasing. According to a December 2012 Permanent Observatory on Prison Deaths report, a 300\% increase in prison suicides has occurred since 1960 (ANSA, b2013). Moreover, suicidal behavior represents a stressful event for officers and other prisoners faced with it. Experts say that prison guards are also becoming less mentally healthy: between 2000 and 2011, 68 suicides were reported among Italian prison workers (ANSA, b2013).

Accurately estimating suicide rates among prisoners is problematic and controversial for various reasons. First, in the United States it is somewhat easier to distinguish between different inmate populations. Long-term sentenced inmates are mostly housed in "State Prisons", whereas "Local Jails" serve remand and short-term sentenced inmates (Table 1). Some studies report that suicide is the third leading cause of death in U.S. prisons and the second in jails (Anasseril, 2006; Metzener, 2002; Esparaza, 1973; Winfree, 1988; White, 2002). During the past three decades, suicide rate in prisons ranged from 18 to 40 per 100,000 and the highest rate was observed for death row inmates (146.5 per 100,000) (Lester, 1998; Anno, 1985; Lester, 1993). Overcrowded urban jails such as those in New York (Malcom, 1975), Atlanta (Frost, 1988) and Miami (Copeland, 1989) have higher suicide rates than non-urban jails. In many other countries, however, this distinction does not exist, and the

Table 1. Prevalence of Medical Conditions among Federal and State Prisoners, Jail Inmates, and the Noninstitutionalized U.S. Population. In the United States it is Somewhat Easier to Distinguish Incarcerated Populations. Prison Inmates are Recognized as a Population with a High Burden of Disease from a Wide Range of Physical and Mental Health Problems with Death as the Ultimate Consequence of these Health Problems. Prisoners are More Likely to Die Prematurely than People who have not been in Custody and Suicide in Custody is one Leading Cause of In-prison Death

\begin{tabular}{|l|c|c|c|c|}
\hline Condition & $\begin{array}{l}\text { Federal } \\
\text { Inmates }\end{array}$ & State Inmates & Jail Inmates & U.S. Population \\
\hline Diabetes Mellitus & $11,1 \%$ & $10,1 \%$ & $8,1 \%$ & $6,5 \%$ \\
\hline Hypertension & $29,5 \%$ & $30,8 \%$ & $27,9 \%$ & $25,6 \%$ \\
\hline Prior myocardial infarction & $4,5 \%$ & $5,7 \%$ & $2,1 \%$ & $3,0 \%$ \\
\hline Persistent Asthma & $7,7 \%$ & $9,8 \%$ & $8,6 \%$ & $7,5 \%$ \\
\hline HIV infection & $0,9 \%$ & $1,7 \%$ & $1,6 \%$ & $0,5 \%$ \\
\hline Symptoms of mental disorders & $39,8 \%$ & $49,2 \%$ & $60,5 \%$ & $10,6 \%$ \\
\hline
\end{tabular}

Modified from: Rich J, Wakeman E, Dickman S. Medicine and the Epidemic of Incarceration in the United States. N Engl J Med 2011; 364(22): 2081-2083. 
term "prison" includes both remand and long-term sentenced inmates. For example, studies on prison suicides in Ireland (Dooley, 1997), England and Wales (Dooley, 1990), Greece (Spinellis, 1997), Finland (Joukamaa, 1997), Italy (Tatarelli, 1999), Austria (Fruehwald, 2000) and Australia (McDonald, 1993) include unsentenced and sentenced prisoners, and most do not distinguish these groups in their analyses. Second, underreporting of suicide also seems to be a problem. If a suicide victim is found and rushed to the hospital, only to die there, records may not show that the victim committed suicide in prison. Also, if the facility chooses to report some deaths as suicides - but not others, for fear of litigationsuicide rates could be inaccurate (Haycock, 1991). Further fuelled by media interest, suicides in correctional facilities can easily escalate into a political scandal. As denounced, a high number of deaths are not fully investigated though they should be; regardless of whether these deaths were actually by suicide, the problem remains that these deaths were left unexplained by officials and health professionals (Haycock, 1989). Third, many prison studies focus on calculating and comparing suicide rates. These have less value, however, as the rates are often calculated incorrectly, and it is difficult to establish an appropriate comparison group. Studies often use the average correctional facility daily census as the denominator, instead of the more appropriate "all imprisoned offenders" in that time period. For example, risk factors such as drug abuse, unemployment, interpersonal conflicts and mental illness are common to both the general population and prisoners. How different would prison suicide rates be if these factors were considered? Studies often compare prison suicide rates with free-community rates, but according to Metzner (2002) this is methodologically incorrect. Instead, the community reference group should be adjusted to match the suicide vulnerability profile of inmates. Controlling for all variables related to suicide in order to find the right community reference group is extremely difficult. Kennedy and Hormant (1988) argue that even comparing correctional institutions is problematic since each has different inmate characteristics and physical plants. Haycock (1993) supports this idea by discussing that confinement is not everywhere equally "suicidogenic". Fourth, immediate post-release suicides are generally left uncounted (Gottlib, 1990; Jones, 2002). Fifth, although a suicide attempt in prison is generally categorized as a type of non-lethal self-injury similar to selfmutilation, it is fundamentally different (Fulwiler, 1997). All self-harming acts may be seen on a continuum of severity, not as distinct problems, since the motivation for selfinjurious behavior is the same for both attempters and completers, and many attempt suicide before they are successful (Liebling, 1993). Some inmates attempt suicide with no intention of ever completing the act, while others persist, using more lethal methods until they are successful.

We recognize the fundamental value of ensuring accurate estimates of suicide rates behind bars, especially in order to verify the efficacy of prevention programs. Given that suicide rate among prisoners is considerably higher than in the general population, we put aside efforts at rate comparison and focus on stressors and risk factors instead, as recommended by Hayes (1995).

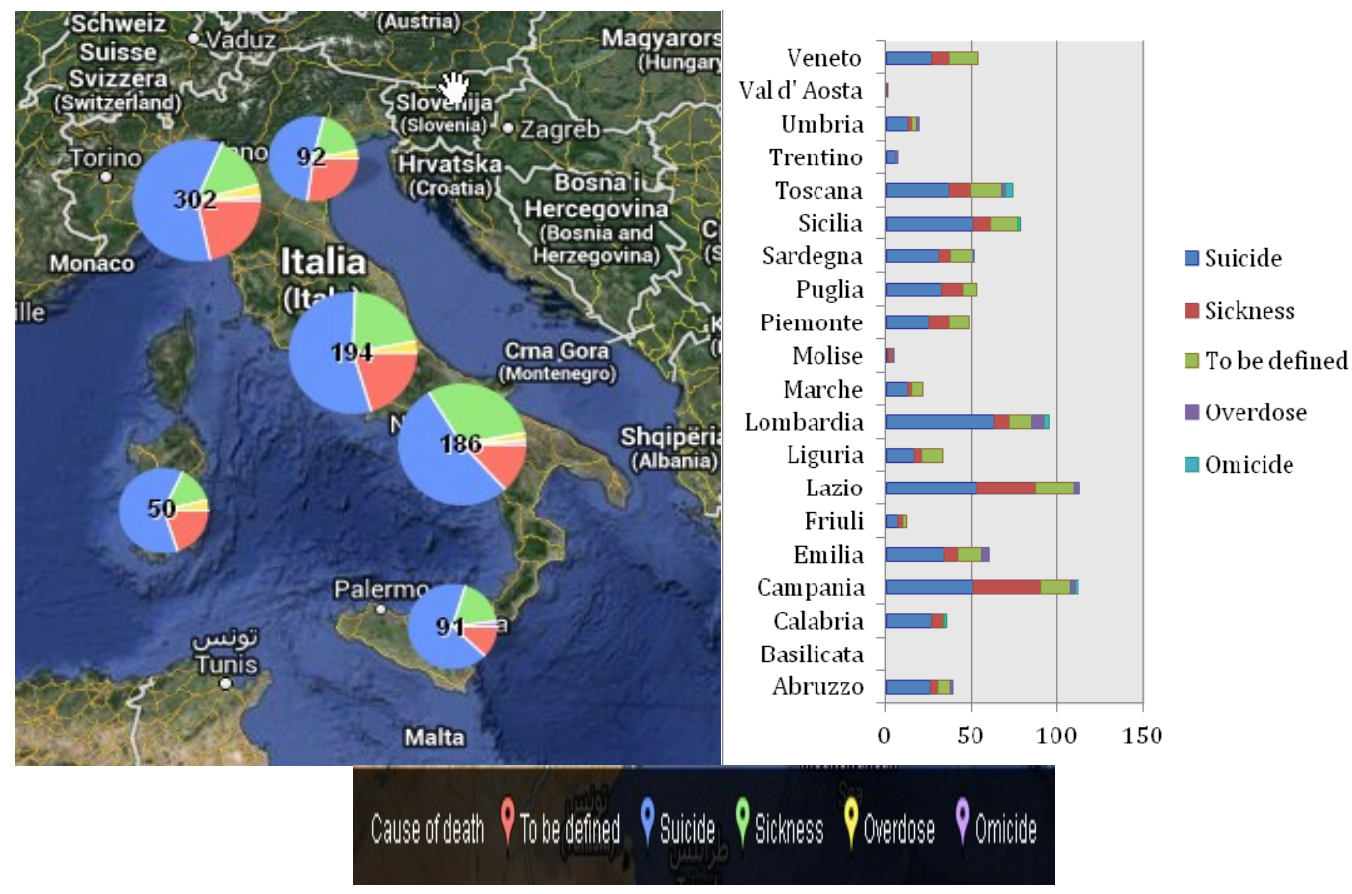

Fig. (3). Almost one thousand deaths are registered from 2002 to 2012 in Italian prisons. The figure points out self-inflicted death as first cause of unnatural decease. 518 (56\% out of 915 prisoners) committed suicide; the second cause is sickness (183, 20\%), followed by prisoners died under unclear circumstances (177, 19\%). Finally, 26 prisoners deceased taking a drug overdose and 11 were victims of homicide. On the left the total distribution is illustrated. On the right the distribution between the twenty Italian national regions is provided.

Edited from: Data journalism project developed by Jacopo Ottaviani. Data sources: Ministero della Giustizia, Ristretti Orizzonti, 2013. Interactive map available online at: http://www.ilfattoquotidiano.it/patrie-galere-deaths-italian-prisons-since-2002-2012/ 


\section{RISK FACTORS}

The causes leading to suicide are complex. Some individuals seem especially vulnerable to suicide when faced with a difficult life event or a combination of stressors. Researchers have identified a number of broad factors that interact to increase an individual's suicide risk. These include: socio-cultural factors, psychiatric conditions, biology, genetics and social stress. The way in which these factors interact to cause suicide is complex and not fully understood. As a group, inmates have higher suicide rates than their community counterparts. Also, suicidal inmates share many characteristics with other non-suicidal inmates, and only few studies have identified specific characteristics that distinguish prisoners who commit suicide from other prisoners.

A wide variety of hypotheses have been put forward to explain high suicide rates in prisons, ranging from medical or psychiatric to sociological ones. Previous studies on the general population have shown that mental disorders are a major contributor to suicide (Barraclough, 1974; Hawton, 2000) and that key social factors associated with suicide are also measures of social disadvantage and exclusion. These factors are more frequent in prisoners than in the general population, and it is therefore not surprising that suicide rates tend to be relatively greater in prison, though the high levels of supervision should mitigate this effect to some degree. Thus, though imprisonment is allegedly ensured to punish criminal behavior, in practice prisons also act as a filter of illness and hold the most socially deprived groups.

A certain number of risk factors for inmate suicides have been reported in scientific literature. However, findings appear to be inconsistent regarding age, sex and race/ethnicity (Camilleri, 1999; Eyland, 1990; Way, 2005; Fruehwald, 2004; He, 2001; Thomson, 1993; Safer Custody Group, 2005; Snow, 2002; Lloyd, 1990). A disparity in the distribution of men and women in prison is ascertained. Thus, most studies have focused on men and those including women had limited numbers for analysis of gender differences. Though prison suicide is considered a male-specific phenomenon, it is important to point out that women in custody are also at high risk of suicide (Bonner, 2000; Paton, 2005). Complete suicide appears to be typically less common in women compared to men (Mumola, 2010) and data on suicides by ageband seem to provide no consistent evidence of rate differences, although numbers vary greatly between studies (Fazel, 2009; Biswanger, 2007; Fazel 2006a). Data on criminological profile and duration of imprisonment as risk factors for suicide appear to be contradictory (Laishes, 1997; Topp, 1979; Hatty 1986; Beckett, 1987). According to the WHO (2007), pre-trial inmates differ from sentenced prisoners with respect to certain key risk factors for suicide. It is important to develop suicide profiles that help explain the heterogeneity of data and that can be used to target high-risk groups and situations. Pre-trail inmates who commit suicide in custody are generally young, unmarried, and first time offenders who have been arrested for minor, usually substance related, offences. They are typically intoxicated at the time of their arrest and commit suicide at an early stage of their confinement (Shaw, 2004), often within the first few hours (because of sudden isolation, shock of imprisonment, lack of information, insecurity about the future) (Winkler, 1992); a second period of risk for pre-trial inmates is near the time of a court appearance, when a guilty verdict and harsh sentencing is anticipated. Compared to pre-trial inmates, those who commit suicide in prison are generally older, violent offenders, serving long sentences and commit suicide after spending considerable time in custody (Bogue, 1995; Hayes, 1993). In these cases suicide is generally precipitated by a conflict within the institution (with other inmates or with the administration), a family conflict or breakup, or a negative legal disposition such as loss of an appeal or the denial of parole. However, as said, in some places different inmate profiles coexist within a single facility.

Moreover, suicide in the period immediately after imprisonment has been increasingly reported, but a limited number of researchers have examined factors associated with the risk of death in ex-prisoners, thus little is known about the risk of suicide after release from prison (Binswanger, 2007; Sattar, 2003). A study in Finland showed that the suicide rate in people within 1 year of release from prison was almost three times the rate in the general population, and suicide in the community was found to be associated with psychosis (Joukamaa, 1998). A study in England and Wales showed that male offenders under criminal justice community supervision were at least ten times more likely to die by suicide than men in the general population (Harding, 1990). Other studies have confirmed that during the first 12 months after release prisoners were at a much greater risk of suicide than the general population, reporting an increase of 3-10 fold (Pratt, 2006). Risk was particularly higher in the first 28 days, during which about a fifth of all suicides occurred. Risk factors for suicide included increased prevalence of mental illness, substance misuse and socioeconomic deprivation. In our opinion, suicide after release from prison must be considered and does not imply that correctional services have no responsibility; on the contrary, these vulnerable offenders should be treated, supported and prepared while they can still be reached inside the prison. On the other hand, being imprisoned is also another stressful event even for healthy inmates (as it deprives the person of important resources).

As said, comparing correctional institutions is problematic since each has different inmate characteristics and physical plants, confinement is not everywhere equally "suicidogenic" and situational factors may play a very important role. Segregation housing or solitary confinement has been cited as one of the major risk factors for prison suicide (Bonner, 2005; Frottier, 2001). Specifically, the conditions of isolation, sensory deprivation and segregation are considered highly aversive and stressful, leading to desperation, isolation, panic (Toch, 1992) and a morbid state of mind (O' Learly, 1989). Suicide tends to occur by hanging, when victims are being held in isolation cells, and during times when presence of staff is at its lowest, such as at night or during weekends (Metzner, 2006). On the other hand, prison overcrowding possibly exacerbates this phenomenon. It has been hypothesized that reduction of inmate population may lead to a decrease in prison suicides (Marcus, 1993; Rabe 2012). Overcrowding, a key issue in Italy, has been tackled by successive Italian governments but little has improved (New York Times, 1995; Russian Today, 2009). The problem is particularly acute in big cities, where inmates are routinely 
packed into cramped, filthy cells, often with only holes in the ground as toilets. They are held in abhorrent prison conditions: four inmates in a two-person cell, less than three square meters of space each, one or two meals a day, unhygienic conditions, reduced medical services, excessive periods of solitary confinement, reduced time spent outside and so forth. Italy's correctional system is in deep crisis: too many inmates and not enough staff and services to safeguard them. Inmates are desperate and so is prison staff and this may partly explain why since 1960 a 300\% increase in prison suicides has been reported (ANSA, b2013).

Remanded, sentenced and released prison inmates share a number of risk factors with the general population that are strongly associated with suicide and largely described in current literature: a history of suicidal behavior, psychiatric disorders and substance abuse.

Several authors found that prison suicide is associated with a history of suicidal behavior (suicide attempts, suicide threats, self-harm), which are considered to be important risk factors for suicidality in general (Arboleda, 1989; Ringel, 1969; Schneider, 2000). In previous studies, a high percentage (43-62\%) of inmates who committed suicide were found to have a history of suicidality (Fruehwald, 2003; Jenkins, 2005). It was assumed, however, that suicide attempts, suicide threats and self-harm were typical of the inmate population in general, thus intervention was not deemed necessary. On the other hand, it has been argued that the majority of inmate suicides was committed by subjects who seemingly made a rational decision to stop living, as they did not communicate their decision to anyone. The remaining suicidal minority managed to succeed in spite of appropriate monitoring and intervention. Whether obvious signs of suicidality have been followed by a psychiatric examination and adequate therapy has never been investigated. If suicidal behavior, defined as non-fatal self-harm and/or statements of suicidal intent, is not followed by referral to psychiatric care, which is required in any psychiatric hospital or institution, these signs of vulnerability represent missed chances for intervention and could be relevant for suicide prevention in this high-risk setting. Several authors found that prison suicide is strongly associated with psychiatric disorders (Sarchiapone, 2009; Blaauw, 2005) and alcohol/drug misuse (Way, 2005; Fazel, 2008b; Martinotti, 2009). Compared to subjects of the same age in the general population, substance misuse and dependence, antisocial personality disorder and psychosis appear to be the most important risk factors (Butler, 2006). Solitary confinement seems to exacerbate symptoms of mental illness, and recommendations have been made to avoid its use in those with pre-existing psychiatric disorders (Arrigo, 2008). Ever since a landmark study on admissions to Sing Sing prison in New York in 1918 highlighted the large number of mentally ill people in custody (Glueck, 1918), a great body of evidence has shown high rates of psychiatric morbidity, although these data are almost entirely based on research done in high-income countries (Table. 2). Around one in seven prisoners has a treatable mental illness. In a systematic review and meta-analysis of 62 surveys of 23000 prisoners, the prevalence of psychosis was around 4\%, major depression $10-12 \%$, and personality disorders 40-70\% (Fazel, 2002). Post-traumatic stress disorder is also thought to affect up to a fifth of prisoners (Goff,
2007) and prisoners of both sexes report histories of severe trauma and abuse (Driessen, 2006). Women seem to have higher rates of most psychiatric disorders than do men (Binswanger, 2010). Drug and alcohol problems are also extremely common (Fazel, 2006b) (Table. 2). Substances can contribute to self-destructive behaviors in all 3 phases of their use-intoxication, withdrawal and chronic usage. To a large extent, factors predicting suicide attempts in substance users are the same as in the general population. While male gender is associated with complete suicide, female gender is associated with suicide attempt (Diekstra, 1993). Other risk factors identified among substance users include parental alcoholism (Glowinski, 2004), drug overdoses (Bradvik, 2007; Hakansson, 2008), stressful life events (interpersonal events, early parental divorce, bullying or physical assaults) (Sher, 2006), history of sexual abuse (Tiet, 2006), being widowed or divorced (Bernal, 2007), and- in women - the perception of parental rejection or neglect (Ehnvall, 2008). Impulsive/aggressive behavior has been associated with suicide attempts in substance users (Koller 2002) and difficulty controlling violent behavior has been observed in those with suicidal ideation; it has been suggested that suicidal behavior and impulsive/aggressive behavior may share complex neurobiological features, including serotonergic dysfunction (Mann, 2007). The high prevalence of mental illness and substance misuse in prisoners might result from an association with violent crime (Wallace, 1998), a shortage of inpatient psychiatric beds (Priebe, 2008) and failure to divert appropriately from court to hospital (Shaw, 1999), high rates of mental illness in homeless people (Fazel, 2008c), failure to identify mental disorders on prison reception (Reed, 2003) and poor subsequent care. Some of these factors are clear indicators of the effectiveness of community mental health services. Cornford and colleagues (Cornford, 2007, 2008) found that a third of English and Welsh prisons in 2005 were not able to offer any cognitive behavioral therapy, and that no systems were in place for transfer of medical information on admission or release in more than $70 \%$ of prisons. Data from a national US survey from 2002-04 showed that a third of prisoners with diagnoses of schizophrenia and bipolar disorder were not treated with psychiatric drugs (Wilper, 2009). Of 80 jails in North Carolina, none used evidence-based screening tools for mental illness, 35\% never contacted mental health services when mentally ill prisoners were released, and $42 \%$ had to transport prisoners to a community provider for mental health assessments (Scheyett, 2009). Unfortunately, few studies of psychiatric morbidity have been conducted in non-western countries, and whether prevalence of mental illness is different elsewhere is unknown. Data suggest some potentially important differences that would merit further examination (Huang, 2006). In Iran, with the ninth largest prison population worldwide, Assadi and colleagues (Assadi, 2006) reported that, compared to western countries, a higher proportion (around 70\%) of male prisoners were dependent on opioids. In India, rates of severe mental illness in custody seem to be close to those in other countries (Banerjee, 2009).

Whatever individual stressors, vulnerabilities and situational factors may be operating, it seems that feelings of hopelessness, a narrowing of future prospects and a loss failure of coping mechanisms ultimately lead prisoners to com- 
Table 2. Prevalence of Mental Disorders in Prisoners in Western Countries in Comparison with the General Population. Although these Data are Based on Research Done in High-income Countries, a Great Body of Evidence has Shown high Rates of Psychiatric Morbidity in Prisoners. Around one in Seven Prisoners has a Treatable Mental Illness. Women Seem to have Higher Rates of Most Psychiatric Disorders than do Men. Drug and Alcohol Problems are Also Extremely Common. In the General Population Mental Disorder is a Major Contributor to Suicide

\begin{tabular}{|l|c|c|c|c|}
\cline { 2 - 5 } \multicolumn{1}{l|}{} & $\begin{array}{l}\text { Male } \\
\text { prisoners (\%) }\end{array}$ & $\begin{array}{l}\text { Male general } \\
\text { population } \\
\text { estimates (\%) }\end{array}$ & $\begin{array}{l}\text { Female prisoners } \\
\text { (\%) }\end{array}$ & $\begin{array}{l}\text { Female general } \\
\text { population estimates } \\
\text { (\%) }\end{array}$ \\
\hline Psychosis & $4 \%$ & $1 \%$ & $4 \%$ & $1 \%$ \\
\hline Depression & $10 \%$ & $2-4 \%$ & $12 \%$ & $5-7 \%$ \\
\hline $\begin{array}{l}\text { Any personality } \\
\text { disorder }\end{array}$ & $65 \%$ & $5-10 \%$ & $42 \%$ & $5-10 \%$ \\
\hline $\begin{array}{l}\text { Antisocial } \\
\text { personality } \\
\text { disorder }\end{array}$ & $47 \%$ & $5-7 \%$ & $21 \%$ & $0,5-1 \%$ \\
\hline $\begin{array}{l}\text { Alcohol } \\
\text { misuse/dependence }\end{array}$ & $18-30 \%$ & $14-16 \%$ & $10-24 \%$ & $4-5 \%$ \\
\hline $\begin{array}{l}\text { Drug } \\
\text { misuse/dependence }\end{array}$ & $10-48 \%$ & $4-6 \%$ & $30-60 \%$ & $2-3 \%$ \\
\hline $\begin{array}{l}\text { Intellectual } \\
\text { disability }\end{array}$ & $0,5-1,5 \%$ & $1 \%$ & $0.5-1.5 \%$ & $1 \%$ \\
\hline $\begin{array}{l}\text { Post-traumatic } \\
\text { disorder }\end{array}$ & $4-21 \%$ & $2 \%$ & $10-21 \%$ & $3 \%$ \\
\hline
\end{tabular}

Modified from: Fazel S, Baillargeon J, The health of prisoners. Lancet 2011; 377: 956-65

mit suicide. Suicide is perceived as the only way out of a desperate and hopeless situation.

\section{PREVENTION}

From a public health viewpoint, the disproportionate burden of physical and psychiatric diseases in prisoners represents both a challenge and an opportunity. In many countries, prisons hold millions of individuals who are out of reach of conventional community-based health systems. For these individuals, prison provides an opportunity for diagnosis, disease management education, counseling and treatment that they would not receive in the general community. Most prisoners return to their communities with physical and psychiatric morbidities occasionally untreated and sometimes worsened. Moreover, much of the increase in the prisoner census is a result of the "War on Drugs" and failure to treat addiction and mental illness as medical conditions. The natural history of these diseases often leads to behaviors that result in incarceration. Health professionals have the chance to advocate for changes in the criminal justice system in order to reduce the number of people behind bars who would be better served in community-based treatment programs and to capitalize on the tremendous public health opportunities to diagnose and treat disease and to link patients to care after release (Rich, 2011). For example, half of all Italian prisoners are charged or sentenced for minor drug crimes. This calls for a major change in drug policy. A three-point reform effort is underway to (i) improve prison conditions, (ii) introduce the crime of torture into the penal code and to (iii) decriminalize personal drug use. The law must also be reformed in order to distinguish between different illegal sub- stances and to promote alternatives to incarceration for drug users. Evidence from randomized controlled trials on treatment of mental health disorders in prisoners is scarce. Inmates with mental disorders who present a serious suicide risk should be provided with adequate psychopharmacological treatment (Daniel, 2006; Perry, 2006; Stallwitz, 2007; Martinotti, 2007; Martinotti 2010). Studies on heroin addiction have underlined the importance of methadone maintenance in prison and continuation after release (Kinlock, 2009). This led to a reduction in criminal activity and number of days of drug use. Considering the high rates of mental disorders and substance misuse among prisoners, according to Pompili (2009), based on experiences in psychiatric inpatient units, in prison settings suicide is best prevented by the development of a comprehensive suicide prevention plan and by efficiently linking patients with community services (Kothari, 2002).

Effective prevention measures depend on the understanding of the reasons underlying high suicide rates in prison (Jenkins, 2005). We support the view that, besides improving social care and preventing social risk factors, recognition of the importance of psychiatric risk factors is also necessary. Both clinical and social needs should be addressed in an integrated and proactive way.

A number of prisons have undertaken comprehensive suicide prevention programs and in some countries national standards and guidelines for suicide prevention in correctional settings have been established. Suicide prevention in prisoners is highlighted in the United States National Strategy for Suicide Prevention (2001), and it is a key component 
of the National Suicide Prevention Strategy for England (2002). An important aspect of these strategies is detection of those at highest risk. Specific risk factors may apply to prisoners, as is for natural-cause mortality in male prisoners (Clavel, 1987) and pregnancy outcomes in female prisoners (Knight, 2005). In a high-risk population, identifying those at highest and most immediate risk is difficult. Shaw (2004) emphasizes the need to recognize the fluctuating and longterm nature of suicide risk in prisoners, to monitor risk continually and to link supervision and other preventive measures to regular assessment. If suicide prevention programs are effective, high-risk profiles may change over time (Frottier, 2002). Evidence also suggests that the days following entrance into prison are a delicate period when suicide prevention measures are most needed and, in particular, hanging suicide needs to be prevented. A full list of recommendations is presented in the Safer Prisons Report (Shaw, 2003). Some measures that should be taken are listed below. (1) Procedures to screen inmates systematically upon their arrival at the facility and throughout their stay in order to identify those who may be at high risk. (2) For prisoners thought to be at risk following reception, initial supervision should take place in dedicated reception wing with appropriate use of restraints and under constant observation. (3) The controlled environments of prisons should really provide opportunities to reduce the incidence of hanging suicides (e.g. providing bed linen that cannot be used in hanging or selfstrangulation, organizing trauma resuscitation training for prison staff, providing staff with emergency response kits in each wing or office, staff carrying cut-down knives to ensure they respond immediately in the event of a hanging, devising guidelines for healthcare workers and prison staff on the management of hanging suicide attempts). Moreover, though ligature points used by those in prisons and hospitals are often below head height, the fact that complete suspension is not required to successfully hang oneself needs to be understood and communicated to those reviewing potential ligature points in institutional settings (Gunnel, 2005). (4) Provision of social support. (5) Information sharing on high-risk inmates should be routine between staff members and when screening reveals a history of mental health service contact relevant information should be obtained within 24 h. (6) Development of sufficient internal resources or links to external community-based mental health services to ensure access to mental health professionals when required for further evaluation and treatment. (7) Detoxification facilities should be available for prisoners with a history of alcohol or drug misuse or dependence. (8) When prisoners are discharged from prison inpatient facilities, they should be followed up within 7 days. (9) Staff should receive regular training (including refreshers) on the recognition, assessment and management of suicide risk. (10) A strategy for debriefing when a suicide occurs to identify ways of improving suicide detection, monitoring and management in correctional settings.

With respect to social intervention, inmates come to correctional settings with certain vulnerabilities to suicide. These, coupled with the crisis of incarceration and the ongoing stressors of prison life may culminate in emotional and social breakdown leading to suicide. Therefore, an important element in suicide prevention in correctional settings is meaningful social interaction (Newbold, 2007). As stated, segregation or isolation cells can increase suicide risk and thus require constant observation. Ideally, the suicidal inmate should be housed in a dormitory or shared cell setting. In some facilities, social support is provided by trained inmate "buddies" or "listeners", who seem to have a good impact on the wellbeing of potential suicide inmates, as they may not trust correctional officers but only other inmates (Hall, 2005; Junker, 2005). Family visits may also be used as a means to foster social support, and as a source of information on the inmate's suicide risk. It is important to note, however, that carelessly contrived or monitored social interventions may be risky. For example, highly suicidal inmates who are placed into shared cells have better access to lethal instruments or unprepared cellmates may not timely alert correctional personnel if a suicide attempt is made. Therefore, placement of a suicidal inmate into a shared cell must never be considered as a substitute for careful monitoring and social support by trained facility staff (Liebling, 2006).

\section{CONCLUSIONS}

Despite the heterogeneity of data from different countries, it is ascertained that suicide rates in prisoners are considerably higher than in the general population. Most suicide cases in literature were from United States and United Kingdom, and this potentially limits generalizability of data. However, there is no evidence that risk estimates are different when comparing studies in English-speaking countries with those from other countries. The heterogeneity reported may also be a result of confounding and selection biases, since most studies are retrospectve, usually indicating they are subject to incomplete recording. Prospective cohort studies are a more reliable means of investigating the relationship between risk or protective factors and suicide in prison; these studies, however, require very large sample sizes. Thus, future research should examine the stress-vulnerability and suicide relationship with large and more representative prisoner samples, with different measures, over time, as effective prevention measures depend on understanding the reasons underlying high suicide rates while in prison and in the immediate period after release.

Prison medical services need improvement. Greater health-care resources should be targeted at prisons, since they represent an opportunity to screen and treat a young, marginalized and ill group (The Lancet, 2009; Glaser, 1993). Where public health systems are adequately resourced, the administrative responsibility for health in prisons should be handed over to public health services because the criminal justice system prioritizes security over healthcare. Screening for physical and mental illness in prisoners should be done by trained individuals, using a standardized instrument, and should include identification of suicide risk. Referral to mental health professionals in screen-positive individuals should follow. Moreover, national suicide prevention strategies should include prison suicide and several national prisonspecific policies and guidelines should be developed. Minimum standards and goals for improvement in relation to the health care of people at high risk in detention should be developed. For instance, treatment guidelines for prisoners with substances misuse and psychosis (including thresholds and recommended waiting times for transfer to hospital) should be outlined. To reduce unhealthy living conditions in prisons 
(including overcrowding, rape and other forms of violence, poor sanitation, unsafe sexual practices, intravenous drug use and tattooing) specific policies should be developed (Fazel, 2011). Again, prisons should provide discharge-planning programmes that allow linkage to community-based health systems for released prisoners. Continuum of treatment between prisons and the community should be ensured to improve effective treatments for mental health, addiction, and infectious diseases. On top, prisons should become more research-friendly environments. Whereas protection of prisoners from abusive and coercive research practices is important, prisoners have been systematically excluded from important clinical studies (Moser, 2004). Finally, the medical profession should take the lead in reforming prison health care, even if this reform means refusing to send prisoners who are in hospital back to prison, where they will suffer inhuman and degrading treatment (The Lancet, 1991). Where the dual ethical obligations of health professionals are in conflict-towards the patients and to society as a wholesolutions that seek justice should be sought in consultation with national medical associations (Office of the United Nations High Commissioner for Human Rights, 2004).

\section{CONFLICT OF INTEREST}

All authors have no relationship with any organization whose interests, financial or otherwise may be affected by the publication of this paper.

\section{ACKNOWLEDGEMENT}

None declared.

\section{REFERENCES}

Anasseril, E. (2006). Preventing suicide in prison: A collaborative responsibility of administrative, custodial, and clinical staff. Journal of the American Academy of Psychiatry and the Law 34, 165-175.

Anno, B.J. (1985). Patterns of suicide in the Texas Department of Corrections. Journal of Prison Jail Health 5, 82-93.

ANSA (Rome, November 22, 2012). Available at: http://www.italianallegro.com/home/news/another-political-failureprison-overcrowding-new-amnesty-soon/

ANSA (Strasbourg, May 3, a2013). Italy's prisons third most overcrowded in Europe Behind Serbia and Greece. Available at: http://www.ansa.it/web/notizie/rubriche/english/2013/05/03/Italyprisons-third-most-overcrowded-Europe_8646685.html

ANSA (Strasbourg, May 27, b2013). Italy forced to fix prison overcrowding in final ruling. European Court of Human Rights finds jails 'inhumane, degrading'. Available at: http://www.ansa.it/web/notizie/rubriche/english/2013/05/27/Italyforced-fix-prison-overcrowding-final-ruling_8775900.html

Arboleda-Florez, J., \& Holley, H. (1985). Predicting suicide behaviours in incarcerated settings. Canadian Journal of Psychiatry 34, 668-674.

Arrigo B.A., \& Bullock, J.L. (2008). The psychological effects of solitary confinement on prisoners in supermax units: reviewing what we know and recommending what should change. International Journal of Offender Therapy and Comparative Criminology 52, 622640.

Assadi, S.M., Noroozian, M., \& Pakravannejad, M. (2006). Psychiatric morbidity among sentenced prisoners: prevalence study in Iran. British Journal of Psychiatry 188, 159-164.

Banerjee, A., Sengupta, A., \& Ray, T. (2009). Persons with major psychiatric illness in prisons-a three year study. Journal of Indian Medical Association 107, 14-16.
Barraclough, B. M., Bunch, B., \& Nelson, B. (1974). A hundred cases of suicide: clinical aspects. British Journal of Psychiatry 125, 355373.

Beckett, S. A. (1987). Suicide in Scottish prison. British Journal of psychiatry 151, 218-221.

Bernal, M., Haro, J. M., \& Bernert, S. (2007). Risk Factors for Suicidality in Europe: results from the ESEMED study. Journal of Affective Disorders 101, 27-34.

Binswanger, I.A., Stern, M.F., \& Deyo, R.A. (2007). Release from prisona high risk of death for former inmates. New England Journal of Medicine 356, 157-165.

Binswanger, I.A., Merrill, J.O., Krueger, P.M., White, M.C., Booth, R.E., \& Elmore, J.G. (2010). Gender differences in chronic medical, psychiatric, and substance-dependence disorders among jail inmates. American Journal of Public Health 100, 476-482.

Blaauw, E., Kerkhof, A.J., \& Hayes, L.M. (2005). Demographic, criminal, and psychiatric factors related to inmate suicide. Suicide and LifeThreatening Behavior 35, 63-75.

Bogue, J., Power, K. (1995). Suicide in Scottish prisons, 1976-1993. Journal of Forensic Psychiatry 6, 527-540.

Bonner, R.L. (2000). Correctional suicide prevention in the year 2000 and beyond. Suicide and Life- Threatening Behavior 30, 370-376.

Bonner, R. L. (2005). A process approach to suicide prevention behind bars: a working guide for program directors and practitioners. Lincoln, NE: Universe Press.

Borrill, J., Burnett, R., \& Atkins, R. (2003). Pattern of self-harm and attempted suicide among white and black/mixed race female prisoners. Criminal Behaviour and Mental Health 13, 229-240.

Bradvik, L., Frank, A., \& Hulenvik, P. (2007). Heroin addicts reporting previous heroin overdoses also report suicide attempts. Suicide and Life-Threatening Behavior 37, 475-481.

Butler, T., Kariminia, A., Levy, M., \& Kaldor, J. (2004). Prisoners are at risk for hepatitis C transmission. European Journal of Epidemiology 19, 1119-1122.

Butler, T., Andrews, G., Allnutt, S., Sakashita, C., Smith, N.E., \& Basson, J. (2006). Mental disorders in Australian prisoners: a comparison with a community sample. Australian \& New Zealand Journal of Psychiatry 40, 272-276.

Camilleri, P., McArthur, M., \& Webb, H. (1999). Suicidal behaviour in prisons: a literature review. Canberra: Australian Catholic University.

Carano, A., De Berardis, D., Campanella, D., Serroni, N., Ferri, F., Di Iorio, G., Acciavatti, T., Mancini, L., Mariani, G., Martinotti, G., Moschetta, F.S., Di Giannantonio, M. (2012) Alexithymia and suicide ideation in a sample of patients with binge eating disorder. Journal of Psychiatric Practice 18(1), 5-11.

Clavel, F., Benhamou, S., \& Flamant, S. (1987). Decreased mortality among male prisoners. Lancet 31, 1012-1014.

Cornford, C., Sibbald, B., \& Baer, L. (2007). A survey of the delivery of health care in prisons in relation to chronic diseases. Manchester: Prison Health Research Network, Primary Care, 2007. Available at: http://www. ohrn.nhs.uk/resource/Research/PCDemo1Rep.pdf (accessed Feb 8, 2010)

Cornford, C.S., Mason, J., \& Buchanan, K., (2008). A survey of primary and specialised health care provision to prisons in England and Wales. Primary Health Care Research \& Development 9, 126-135.

Copeland, A. (1989). Fatal suicidal hangings among prisoners in jail. Medicine Science and the Law 29, 341-345.

Dalton, V. (1999). Death and dying in prison in Australia: national overview, 1980-1998. Journal of Law Medicine \& Ethics 27, 269-274.

Daniel, A.E. (2006). Preventing suicide in prison: A Collaborative Responsability of Administrative, Custodial and Clinical Staff. Journal of American Academy of Psychiatry and the Law 34(2), 165-175.

David, N., \& Tang, A. (2003). Sexually transmitted infections in a young offenders institution in the UK. International Journal of STD \& AIDS 14, 511-513.

Department of Health (2002). National Suicide Prevention Strategy for England. London. United Kingdom: Her Majesty' s Stationery Office.

De Berardis, D., Marini, S., Piersanti, M., Cavuto, M., Perna, G., Valchera, A., Mazza, M., Fornaro, M., Iasevoli, F., Martinotti, G., Di Giannantonio, M. (2012). The Relationships between Cholesterol and Suicide: An Update. ISRN Psychiatry Dec 23, 387901. 
Diekstra, R. F., \& Gulbinat, W. (1993). The epidemiology of suicidal behaviour: a review of three continents. World Health Statistics Quarterly 46, 52-68.

Dooley, E. (1990). Prison suicide in England and Wales, 1972-1987. British Journal of Psychiatry 156, 40-45.

Dooley, E. (1997). Prison suicide-politics and prevention: A view from Ireland. Crisis 18, 185-189.

Driessen, M., Schroeder, T., Widmann, B., von Schonfeld, C., \& Schneider, F. (2006). Childhood trauma, psychiatric disorders, and criminal behavior in prisoners in Germany: a comparative study in incarcerated women and men. Journal of Clinical Psychiatry 67, 14861492.

Durand, C.J., Burtka, G.J., \& Federman, E.J. (1995). A quarter century of suicides in a major urban jail: implications for community psychiatry. American Journal of Psychiatry 152, 1077-1080.

Ehnvall, A., Parker, J., \& Hadzi-Pavlovic (2008). Perception of Rejecting and Neglectful Parenting in Childhood relates to lifetime suicide attempt for females- but not for males. Acta Psychiatrica Scandinavica $117,50-56$.

Eyland, S. (1990). NSW prisoners 1988. Summary of characteristics. Sydney: NSW Department of Corrective Services. Report no. 7.

Esparaza, R. (1973). Attempted and committed suicide in county jails. In Danto, B. (Ed.). Jailhouse Blues (pp 27-46). Orchard Lake, MI: Epic.

Fazel, S., \& Baillargeon, J. (2011). The health of prisoners. Lancet 377, 956965.

Fazel, S., \& Danesh, J. (2002). Serious mental disorder in 23000 prisoners: a systematic review of 62 surveys. Lancet 359, 545-550.

Fazel, S., Benning, R., \& Danesh, J. (2005). Suicides in male prisoners in England and Wales, 1978-2003. Lancet 366, 1-2.

Fazel, S., Cartwright, J., \& Norman-Nott, A. (2008a). Suicide in prisoners: a systematic review of risk factors. Journal of Clinical Psychiatry 69, 1721-1731.

Fazel, S., Grann, M., Kling, B., \& Hawton, K. (2010). Prison suicide in 12 countries: an ecological study of 861 suicides during 2003-2007. Social Psychiatry and Psychiatric Epidemiology DOI:10.1007/s 00127-010-0184-4.

Fazel, S., \& Benning, R. (2009). Suicides in female prisoners in England and Wales, 1978-2004. British Journal of Psychiatry 194, 183-184.

Fazel S., \& Benning, R. (2006a). Natural deaths in male prisoners: a 20-year mortality study. European Journal of Public Health 36, 441-444.

Fazel, S., Bains, P., \& Doll, H. (2006b). Substance abuse and dependence in prisoners: a systematic review. Addiction 101, 181-191.

Fazel, S., Xenitidis, K., \& Powell, J. (2008b). The prevalence of intellectual disabilities among 12,000 prisoners-a systematic review. International Journal of Law and Psychiatry 31, 369-373.

Fazel, S., Khosla, V., Doll. H., \& Geddes, J. (2008c). The prevalence of mental disorders among the homeless in Western countries: systematic review and meta-regression analysis. PLoS Medicine 5, 225.

Frost, R., \& Hanzlick, P. (1988). Deaths in custody. American Journal of Forensic and Medicine and Pathology 9, 207-211.

Frottier, P., Fruhwald, S., Ritter, K., \& Konig, F. (2001).Deprivation versus importation: a model explaining the increase of suicide rates in custody. Fortschr Neurol Psychiatr 69, 90-95.

Frottier, P., Fruhwald, S., \& Ritter, K. (2002). Jailhouse Blues revisited. Social Psychiatry and Psychiatric Epidemiology 37, 68-73.

Fruehwald, S., Frottier, P., \& Eher, R. (2000). Prison suicide in Austria 1975-1997. Suicide and Life- Threatening Behavior 30(4), 360-369.

Fruehwald, S., Frottier, P., \& Matschnig, T. (2003). The relevance of suicidal behaviour in jail and prison suicides. European Psychiatry 18, 161-165.

Fruehwald, S., Matschnig, T., Koenig, F., Bauer, P., \& Frottier, P. (2004). Suicide in custody: case-control study. British Journal of Psychiatry 185, 494-498.

Fulwiler, C., Forbes, C., \& Santangelo, S.L. (1997). Self-mutilation and suicide attempt: distinguishing features in prisoners. Journal of the American Academy and Psychiatry Law 25, 69-77.

Glaser, J., \& Greifinger, R. (1993). Correctional health care: a public health opportunity. Annals of Internal Medicine 118, 139-145.
Glowinski, A. L., Jacob, T., \& Bucholz A. (2004). Paternal Alcohol Dependence and Offspring suicidal behaviors in a children -of -twins study. Drug and Alcohol Dependence 76, 69-77.

Glueck, B. (1918). A study of 608 admissions to Sing Sing prison. Mental Hygiene 2, 85-151.

Goff, A., Rose, S., \& Purves, D. (2007). Does PTSD occur in sentenced prison populations? A systematic literature review. Criminal Behaviour and Mental Health 17, 152-162.

Gottlib, P., \& Gabrielsen, G. (1990). The future of homicide offenders: results from a homicide project in Copenhagen. International Journal of Law and Psychiatry 13, 191-205.

Green, C., Kendall, K., \& Andre, G. (1993). A study of 133 suicides among Canadian federal prisoners. Medicine, Science and the Law 33, 121-127.

Gunnell, D., Bennewith, O., \& Hawton, K. (2005). The epidemiology and prevention of suicide by hanging: a systematic review. International Journal of Epidemiology 34, 433-442.

Haycock, J. (1991). Capital crimes: suicides in jail. Death Stud 15, 417-433.

Haycock, J. (1989). Race and suicide in jails and prisons. Journal of the National Medical Association 81, 405-411.

Haycock, J. (1993). Comparative suicide rates in different types of involuntary confinement. Medical Science and the Law 33, 128-138.

Hayes, L. (1989). National study of jail suicides: seven years later. Psychiatry $Q$ 60(1), 7-29.

Hayes, L. M. (1995). Prison suicide: An overview and guide to prevention. Washington DC7 US Justice Department, National Institute of Corrections.

Hayes, L.M (1993). Jail suicide-prevention through written protocol (part 1). Crisis 14, 11-13.

Hakansson, A., Bradvik, L., \& Schlyter, F. (2010). Factors associated with the hystory of attempted suicide. Crisis 31(1), 12-21.

Hakansson, A., Schlyter, F., \& Berglund, M. (2008). Factors associated with hystory of non-fatal overdose among opioid users in the Swedish criminal justice system. Drug and Alcohol Dependence 94, 48-55.

Hall, B., \& Gabor, P. (2004). Peer suicide prevention in a prison. Crisis 25(1), 19-26.

Harding-Pink, D. (1990). Mortality following release from prison. Medicine, Science and the Law 30, 12-16.

Hatty, S.E., \& Walker, J.R. (1986). A national study of deaths in Australian prison. Canberra: Australian Institute of Criminolgy.

Hawton, K., \& van Heeringen, K. (2000). The international handbook of suicide and attempted suicide. John Wiley and Sons: Chichester.

He, X., Felthous, A., Holzer, C., Nathan, P., \& Veasey, S. (2001). Factors inprison suicide. Journal of Forensic Science 46, 896-901.

Huang, G., Zhang, Y., Momartin, S., Cao, Y., \& Zhao, L. (2006). Prevalence and characteristics of trauma and posttraumatic stress disorder in female prisoners in China. Comprehensive Psychiatry 47, 20-29.

Jenkins, R., Bhugra, D., \& Meltzer, H. (2005). Psychiatric and social aspects of suicidal behaviour in prisons. Psychological Medicine 35, 257269.

Jones, R., Gruer, L., \& Gilchrist, G. (2002). Recent contact with health and social services by drug misusers in Glasgow who died of a fatal overdose in 1999. Addiction 97, 1517-1522.

Joukamaa, M. (1997). Prison suicide in Finland 1969-1992. Forensic Science International 89, 167-174.

Joukamaa, M. (1998). The mortality of released Finnish prisoners: a 7 year follow-up study of the WATTU project. Forensic Science International 96, 11-19.

Junker, G., Beeler, B., \& Bates, J. (2005). Using a Trained Inmate Observers for Suicide Watch in a Federal Correctional Setting: A Win-Win Solution. Psychological Services 2(1), 20-27.

Karminia, A., Butler, T.G., \& Corben SP. (2007). Extreme cause specific mortality in a cohort of adult prisoners- 1988 to 2002. A datalinkage study. International Journal of Epidemiology 36, 310-316.

Kennedy, D. B., \& Hormant, R. J. (1988). Predicting custodial suicides: Problems with the use of profiles. Justice Quarterly 5, 441-456.

Kinlock, T.W., Gordon, M.S., Schwartz, R.P., Fitzgerald, T.T., \& O’Grady, K.E. (2009). A randomized clinical trial of methadone maintenance for prisoners: results at 12 months postrelease. Journal of Substance Abuse Treatment 37, 277-285.

Knight, M., \& Plugge, E. (2005). The outcomes of pregnancy among imprisoned women: a systematic review. BJOG 112(11), 1467-1474. 
Kokkevi, A., \& Stefanis, C. (1995). Drug abuse and psychiatric comorbidity. Comprehensive Psychiatry 36, 329-337.

Koller, G., Preuss, U. W., \& Bottlender, M. (2002). Impulsivity and aggression as predictors of suicide attempts in alcoholics. European Archives of Psychiatry and Clinical Neuroscience 252, 155-160.

Kothari, G., Marsden, J., \& Strang, J. (2002). Opportunities and obstacles for effective treatment of drug misusers in the criminal justice system in England and Wales. British Journal Criminology 42, 412432.

Kouri, E.M., Pope, H.G., Jr, Powell, K.F., Oliva, P.S., \& Campbell, C. (1997). Drug use history and criminal behavior among 133 incarcerated men. American Journal of Drug and Alcohol Abuse 23, 413-419.

Laishes, J. (1997). Inmates suicides in the Correctional Service of Canada. Crisis 18(4), 157-162.

Lester, D. (1998). Prison suicide rates by state from 1984-1993. Psychological Reports 83, 514.

Lester, D., \& Danto, B.L. (1993). Suicide Behind Bars: Prediction and Prevention (pp 18-21). Philadelphia: The Charles Press.

Liebling, A. (1993). Suicides in young prisoners: a summary. Death Studies 17, 381-409.

Liebling, A. (1999). Prison suicide and prisoners coping. In: Prisons, crime and justice: a Review of research. vol 26. University of Chicago.

Liebling, A. (2006). The role of the prison environment in prison suicide and prisoner distress. In: Dear, G.E. (Ed.). Preventing suicide and other self-harm in prison (pp. 16-28). Basingstoke (UK): PalgraveMacmillan.

Lloyd, C. (1990). Suicide and self-injury in prison: a literature review. London: Home Office.

Malcom, B.J. (1975). Today's problems in penology. New York State Journal of Medicine 75, 1812-1814.

Mann, J. J., \& Currier, D. (2007). A review of prospective studies of biological predictors of suicidal behavior in mood disorders. Archives of Suicide Research 11, 3-16.

Marcus, P., \& Alcabes, P. (1993). Characteristics of suicides by inmates in an urban jail. Hospital \& Community Psychiatry 44, 256-261.

Martinotti, G., Di Nicola, M., Tedeschi, D., Andreoli, S., Reina, D., Pomponi, M., Mazza, M., Romanelli, R., Moroni, N., De Filippis, R., Di Giannantonio, M., Pozzi, G., Bria, P., Janiri, L. (2010). Pregabalin versus naltrexone in alcohol dependence: a randomised, doubleblind, comparison trial. Journal of Psychopharmacology 24(9), 1367-74

Martinotti, G., Di Nicola, M., Romanelli, R., Andreoli, S., Pozzi, G., Moroni, N., Janiri, L. (2007). High and low dosage oxcarbazepine versus naltrexone for the prevention of relapse in alcoholdependent patients. Human Psychopharmacology 22(3), 149-56

Martinotti, G., Carli, V., Tedeschia, D., Di Giannantonio, M., Roy, A., Janiri, L., \& Sarchiapone, M. (2009). Mono-and polysubstance dependent subjects differ on social factors, childhood trauma, personality, suicidal behaviour, and comorbid Axis I diagnoses. Addictive Behaviors 34, 790-793.

McDonald, D., \& Thompson, N. J. (1993). Australian deaths in custody, 1980-1989. 2 Causes. Medical Journal of Australia 159, 581-585.

Metzner, J.L. (2002). Class action litigation in correctional psychiatry. Journal of the American Academy of Psychiatry and the Law 30, 19-29.

Metzner, J., \& Hayes, J. (2006). Suicide prevention in Jails and Prisons. In: Simon, R., Hales, R., (Eds.). Textbook of Suicide Assessment and Management (pp. 139-155). Washington (DC): American Psychiatric Publishing.

Ministero della Giustizia, Ristretti Orizzonti (2013). Data journalism project developed by Jacopo Ottaviani. Interactive map. Available at: http:// www.ilfattoquotidiano.it/patrie-galere-deaths-italian-prisonssince-2002-2012/

Ministero della Giustizia (2011). Detenuti presenti-Aggiornamento al 31 Dicembre 2011. Available at http://www.giustizia.it/giustizia/it/mg_1_14_1.wp?previsiousPage=mg_1_14\&contentId=SST7200 06

Moser, D.J., Arndt, S., \& Kanz, J.E. (2004). Coercion and informed consent in research involving prisoners. Comprehensive Psychiatry 45, 1-9.

Mumola, C.J. (accessed June 4, 2010). Suicide and homicide in state prisons and local jails.Bureau of Justice Statistics Special Report. August
2005. Available at: http:// bjs.ojp.usdoj.gov/index.cfm?ty=pbdetail\&iid=1126

New York Times (February 28, 1995): Bursting Population Overwhelms Italy's Prisons. Available at: http://www.nytimes.com/1995/02/28/ world/bursting-population-overwhelms-italy-s-prisons.html

Newbold G. (2007). The problem of prisons: Corrections reform in New Zealand since 1840. Wellington: Dunmore Publishing Ltd.

Office of the United Nations High Commissioner for Human Rights (2004). Istanbul protocol: Manual on the effective investigation and documentation of torture and other cruel, inhuman or degrading treatment and punishment. Geneva: United Nations.

O'Leary, W. D. (1989). Custodial suicide: evolving liability in corrections. Psychiatry Quarterly 60, 31-71.

Paton, J., \& Jenkins, R. (2005). Suicide and suicide attempts in prison. In: Hawton, K., (Ed.). Prevention and treatment of suicidal behaviour: from science to practice (pp 307-334). Oxford: University Press.

Perry, A., Coulton, S., \& Glanville, J. (2006). Interventions for drug-using offenders in the courts, secure establishments and the community. Cochrane Database of Systematic Reviews 19(3), CD005193.

Pompili, M., Lester, D., \& Innamorati, M. (2009). Preventing Suicide in Jails and Prisons: Suggestions from Experience with Psychiatric Inpatients. Journal of Forensic Science 54(5), 1155-1162.

Pratt, D., Piper, M., \& Appleby, L. (2006). Suicide in recently released prisoners: a population-based cohort study. Lancet 368, 119-123.

Preti, A., \& Cascio, M. (2006). Prison suicide and self-harming behaviours in Italy 1990-2002. Medicine, Science \& Law 46, 127-134.

Priebe, S., Frottier, P., \& Gaddini, A. (2008). Mental health care institutions in nine European countries, 2002 to 2006. Psychiatric Services 59, 570-573.

Rabe, K. (2012). Prison structure, inmate mortality and suicide risk in Europe. International Journal of Law and Psychiatry 35(3), 222230.

Reed, J. (2003). Mental health care in prisons. British Journal of Psychiatry $182,287-288$.

Rich, J., Wakeman, E., \& Dickman, S. (2011). Medicine and the Epidemic of Incarceration in the United States. New England Journal of Medicine 364(22), 2081-2083.

Ringel, E. (1969). Selbstmordverhuetung (suicide prevention). Bern: Huber.

Ronald, L., \& Bonner, D. (2006). Stressful segregation housing and psychosocial vulnerability in prison suicide ideators. Suicide and LifeThreatening Behavior 36(2), 250-254.

Russian Today (November 12, 2009). Italy's invisible dead. Available at: http://rt.com/news/italy-invisible-dead/

Safer Custody Group (2005). Self-inflicted deaths in custody: Six-year Overview: 1997/2000 to 2004/2005 [internal report]. London, United Kingdom: National Offender Managment Service

Salive, M.E., Smith, G.S., \& Brewer, T.F. (1990). Death in prison: changing mortality patterns among male prisoners in Maryland, 1979-87. American Journal of Public Health 80, 1479-1480.

Sarchiapone, M., Carli, V., Di Giannantonio, M., \& Roy, A. (2009). Risk factors for attempting suicide in prisoners. Suicide Life Threat Behav 39(3), 343-350.

Sattar, G. (2003). The death of offenders in England and Wales. Crisis 24, 17-23.

Schaller, G., Zimmermann, C., \& Raymond, L. (1999) Risk factors in selfinjurious behavior in a Swiss prison (in French). Sozial Praventivmedizin 41, 249-256.

Shaw, J., Creed, F., Price, J., Huxley, P., \& Tomenson, B. (1999). Prevalence and detection of serious psychiatric disorder in defendants attending court. Lancet 353, 1053-1056.

Shaw, J., Baker, D., \& Hunt, I. (2004). Suicide by prisoners. British Journal of Psychiatry 184, 263-267.

Shaw, J., Appleby, L., \& Baker, D. (2003). Safer Prisons- A National Study of Prison Suicides 1999-2000 by the National Confidential Inquiry into Suicides and Homicides by People with Mental Illness. London: Department of Health.

Scheyett, A., Vaughn, J., \& Taylor, M. (2009). Screening and access to services for individuals with serious mental illnesses in jails. Community Mental Health Journal 45, 439-446.

Schneider, B., Philipp, M., \& Muller, M.J. (2000). Psychopathological predictors of suicide in patients with major depression during a 5-year follow-up. European Psychiatry 16, 283-288. 
Sher, L. (2006). Alcoholism and suicidal behavior: a clinical overview. Acta Psychiatrica Scandinavica 113, 13-22.

Snow, L., Paton, J., \& Oram, C. (2002). Self-inflicted deaths during 2001: an analysis of trends. British Journal of Forensic Practice 4, 3-17.

Spinellis, C. D., \& Themeli, O. (1997). Suicide in Greek prisons: 1977 to 1996. Crisis 18, 152-156.

Stallwitz, A., \& Stover, H. (2007). The impact of substitution treatment in prisons - a literature review. International Journal of Drug Policy 18, 464-474.

Tatarelli, R., Mancinelli, I., Taggi, F., \& Polidori, G. (1999). Prison suicides in Italy in 1996-1997. European Psychiatry 14, 109-110.

The Lancet (2009). Health care for prisoners and young offenders. Lancet 373, 603.

The Lancet (1991). Health care for prisoners: implications of "Kalk's refusal”. Lancet 337, 647-648.

Thomson, N. J., \& McDonald, D. (1993). Australian deaths in custody, 1980-1989: causes. Medical Journal of Australia 159, 577-581.

Tiet, Q., \& Finney, J. W. (2006). Recent Sexual Abuse, physical abuse, and suicide attempts among male veterans seeking psychiatric treatment. Psychiatric Services 57, 107-113.

Toch, H. (1992). Mosaic fo despair: Human breakdown in prisons. Washington DC: The American Psychological Association.

Topp, D. (1979). Suicide in prison. British Journal of Psychiatry 134, 24-27.

US Department of Health (2001). National Strategy for Suicide Prevention: Goals and Objectives for Action. Rockville. MD: US Dept Health and Human Services.
Way, B.B., Miraglia, R., Sawyer, D.A., Beer, R., \& Eddy, J. (2005). Factors related to suicide in New York state prisons. International Journal of Law and Psychiatry 28, 207-221.

Wallace, C., Mullen, P., \& Burgess, P. (1998). Serious criminal offending and mental disorder: case linkage study. British Journal of Psychiatry $172,477-484$.

Walmsley, R. (2009). World prison population list, $8^{\text {th }}$ (ed.). London: King's College London International Centre for Prison Studies.

White, T.W., Schimmel, D.J., \& Frickey, R. (2002). A comprehensive analysis of suicide in federal prisons: a fifteen-year review. Journal of Correctioanl Health Care 9, 321-345.

Wilper, A.P., Woolhandler, S., \& Boyd, J.W. (2009). The health and health care of US prisoners: results of a nationwide survey. American Journal of Public Health 99, 666-672.

Winfree, L.T. (1988). Rethinking American jail death rates. Policy Studies Review 7, 641-689.

Winkler, G.E. (1992). Assessing and responding to suicidal jail inmates. Community Mental Health Journal 28, 317-326.

Wobeser, W.L., Datema, J., Bechard, B., Ford, P. (2002). Causes of death among people in custody in Ontario, 1990-1999. Canadian Medical Association Journal 167, 1109-1113.

World Health Organization (2005). Background of SUPRE. Prevention of suicidal behaviours: a tesk for all (Retrivied on May 7, 2008). Geneva: World Health Organization.

World Health Organization (2007). Preventing suicide in jail and prisons. WHO: Library Cataloguing-in-Publication Data.

Received: July 08, 2013

Revised: August 05, 2013

Accepted: August 13, 2013

(C) Cinosi et al.; Licensee Bentham Open.

This is an open access article licensed under the terms of the Creative Commons Attribution Non-Commercial License (http://creativecommons.org/licenses/by-nc/3.0/) which permits unrestricted, non-commercial use, distribution and reproduction in any medium, provided the work is properly cited. 